\title{
Impacts of Forest Harvest on Active Carbon and Microbial Properties of a Volcanic Ash Cap Soil in Northern Idaho
}

\author{
Deborah S. Page-Dumroese ${ }^{1}$, Matt D. Busse ${ }^{2}$, Steven T. Overby ${ }^{3}$, Brian D. Gardner ${ }^{4}$, \\ Joanne M. Tirocke ${ }^{1}$ \\ ${ }^{1}$ USDA Forest Service, Rocky Mountain Research Station, Moscow, USA \\ ${ }^{2}$ USDA Forest Service, Pacific Southwest Research Station, Davis, USA \\ ${ }^{3}$ USDA Forest Service, Rocky Mountain Research Station, Flagstaff, USA \\ ${ }^{4}$ USDA Natural Resource Conservation Service, Moscow, USA \\ Email: *ddumroese@fs.fed.us
}

Received 4 December 2014; revised 27 December 2014; accepted 6 January 2015

Copyright (C) 2015 by authors and Scientific Research Publishing Inc.

This work is licensed under the Creative Commons Attribution International License (CC BY).

http://creativecommons.org/licenses/by/4.0/

C) (i) Open Access

\begin{abstract}
Soil quality assessments are essential for determining impacts on belowground microbial community structure and function. We evaluated the suitability of active carbon (C), a rapid field test, as an indicator of soil biological quality in five paired forest stands (clear cut harvested 40 years prior and unharvested) growing on volcanic ash-cap soils in northern Idaho. Active $\mathrm{C}$ was compared with several traditional measures of soil microbial properties (microbial biomass, respiration, fungal hyphal biomass, bacterial number and biomass and PLFA community structure). Despite the significant differences in forest vegetation between paired stands, no differences in active $C$ and only a few significant differences in microbial properties were detected. Total bacteria (microscope counts) and PLFA signatures (gram positive bacteria, gram negative bacteria, actinomycetes) were significantly higher in the managed stands. Our results indicate that either mineral soil biological properties in managed stands were relatively unaffected at the time of harvest or some biological recovery occurred 40 years later. Additionally, volcanic ash-cap soils in moist ecosystems could be highly resilient to the impacts of harvest operations and therefore few significant biological changes could be detected.
\end{abstract}

\section{Keywords}

Soil Quality, Forest Soil, Soil Monitoring, Soil Organic Matter

\footnotetext{
"Corresponding author.
}

How to cite this paper: Page-Dumroese, D.S., Busse, M.D., Overby, S.T., Gardner, B.D. and Tirocke, J.M. (2015) Impacts of Forest Harvest on Active Carbon and Microbial Properties of a Volcanic Ash Cap Soil in Northern Idaho. Open Journal of Soil Science, 5, 11-19. http://dx.doi.org/10.4236/ojss.2015.51002 


\section{Introduction}

Changes in the labile fraction of the soil organic matter pool can provide an indication of both short- and longterm changes in soil quality that are a direct response to land management practices. Although there are a myriad of soil physical, chemical or biological properties that can be tested for soil quality assessments [1] to maintain forest sustainability, there are few consistently used measures that can be easily applied [2]. In addition to the limited accessibility and applicability of many field and laboratory tests, application of many testing procedures to forests and forest soils can also be a challenge [3]. Of particular concern is an appropriate surrogate test for biological activity after a given management activity. Indicators include potentially mineralized nutrients, decomposition, microbial biomass, total or active carbon, or organic matter content.

Assessments of soil quality often include a measure of soil organic matter, because it is critical for maintaining site productivity. In forest soils, organic matter content has been linked to soil water availability, nutrient supply, soil aggregation, and disease incidence or prevention [4] and contributes to numerous soil functions [3] [5]. In addition, forest management practices that impact organic matter accumulation and decomposition could affect future tree growth and site productivity [6].

Forest harvest or site preparation activities that remove the surface organic horizons may cause changes in soil organic matter that affect long-term productivity. For instance, loss of soil organic matter may alter soil productivity by leading to changes in the hydrologic function, erosion rates, soil water retention, or microbial activity [3] [7]. Total soil organic matter, however, is not a ready indicator of how management might affect the more labile fraction of soil organic carbon and it is therefore important to use methods that expresses a change in organic matter and other biological properties [8] and that forest soil scientists or other land managers can use to quickly assess potential impacts.

Tephra-derived forest soils have unique physical and chemical characteristics that affect their responses to harvest operations. Volcanic materials have undeveloped crystalline structure and weather rapidly in humid environments, producing soils that are characterized by high water holding capacity, cation exchange capacity, and their ability to stabilize organic matter [9]. These soil types are widely distributed in northern Idaho and support highly productive forests [10].

Forest harvesting can result in changes in the active fractions of organic matter and result in alteration of microbial properties or biomass or changes in $\mathrm{C}$ and $\mathrm{N}$ content [1] [11]. The active $\mathrm{C}$ pool can be a sensitive indicator of changes in other biological properties such as microbial biomass $\mathrm{C}$ [12], particulate organic matter [13] and soil carbohydrates [14]; however, it has not been widely tested in forest soils. Given that a rapid assessment of soil microbial response to land management is needed and that a measure of biological activity should reflect organic matter quality, our objectives were to 1) test the rapid field measure of active $\mathrm{C}$ as an indicator of soil biological quality, and 2) determine the long-term impact of forest harvesting on soil microbial and chemical properties.

\section{Methods and Materials}

\subsection{Site Description}

Soils were collected from the forest floor and surface $0-5 \mathrm{~cm}$ of the mineral soil in 5 different stands each of a 40-year-old managed forest and an unharvested control in northern Idaho during a 3-week time period in June. The unharvested stands were a mixed conifer forest type with an overstory consisting primarily of grand fir (Abies grandis (Douglas ex D. Don) Lindl.), western redcedar (Thuja plicata Donn ex D. Don) and western hemlock (Tsuga heterophylla (Raf.) Sarg.) with a small amount of Douglas-fir (Pseudotsuga menziesii (Mirb.) Franco (Table 1). Canopy coverage was visually estimated, diameter was measured at $1.4 \mathrm{~m}$ from ground level, and height was measured from ground level to the top of the terminal leader.Managed stands were clearcut harvested, dozer piled, and the piles burned; a typical harvest system from 40 yrs ago. Species composition for the managed stands consisted of grand fir, Douglas-fir, lodgepole pine (Pinus contorta (Douglas ex Loudon)), grand fir, western white pine (Pinus monticola (Douglas ex D. Don)), and ponderosa pine (Pinus ponderosa Lawson \& C. Lawson). Both the harvested and unharvested stands were selected because they occur on the Threebear soil series (Medial over loamy, amorphic over mixed, superactive, Frigid Alfic Udivitrand) [15]. The Threebear series is an extensive soil in northern Idaho, (USDA-NRCS Major Land Resource Area 43A) and occurs on structural benches, hills and mountain foots lopes formed in eolian and alluvial material with a thick $(>30 \mathrm{~cm})$ mantle 
Table 1. Overstory species and mean canopy coverage, diameter, and height for managed and unharvested stands. NM indicates that this species was not measured for diameter or height.

\begin{tabular}{ccccccc}
\hline Tree species & \multicolumn{3}{c}{ Managed stand } & \multicolumn{3}{c}{ Unharvested stand } \\
\hline & Canopy coverage (\%) & Diameter (cm) & Height (m) & Canopy coverage (\%) & Diameter (cm) & Height (m) \\
A. grandis & 20 & 23.8 & 16.5 & 64 & 50.3 & 36.8 \\
L. occidentalis & 0 & 0 & 0 & $<1$ & NM & NM \\
P. contorta & 28 & 25.1 & 12.4 & 0 & 0 & 0 \\
P. monticola & 7 & 23.5 & 15.6 & 0 & 0 & 0 \\
P. ponderosa & 5 & 32.5 & 15.1 & 0 & 35.2 & 30.8 \\
P. menziesii & 40 & 29.4 & 15.7 & 3 & 69.8 & 28.6 \\
T. plicata & 0 & 0 & 0 & 17 & 16 & 70.5 \\
T. heterophylla & 0 & 0 & 0 & & 33.6 \\
\hline
\end{tabular}

of volcanic ash. The soil is mapped at elevations ranging from 2800 to 3500 feet and is one of the most productive soils in the forested lands of northern Idaho, and as such is of great interest to land managers as a unit to manage and monitor for changes in soil quality.

\subsection{Soil Sampling}

In each forest stand ( 5 paired managed and unharvested stands), 3 randomly selected locations within each forest site $(5$ sites $\times 3$ soil samples $=15$ total samples $)$ were selected and cores $(2 \mathrm{~cm}$ dia. $)$ were collected to a depth of $5 \mathrm{~cm}$ in the mineral soil. Soils were immediately placed in a cooler until the end of the day when they were cooled to $4^{\circ} \mathrm{C}$ until processing. For each forest condition we collected 15 soil cores. Moist soil samples were subsampled for all analyses. Bulk density was calculated as dry mass per volume of the cylinder. No rocks were present in this soil; therefore total bulk density is presented. Soil $\mathrm{pH}$ was conducted on a 2:1 water:soil paste. Total $\mathrm{C}$ and $\mathrm{N}$ in the forest floor and mineral soil were analyzed on a LECO CN analyzer (LECO Corp, St. Joseph, MI). Cation exchange capacity (CEC) was determined with ammonium acetate extract and base saturation was calculated as the sum of the cations [16]. Active carbon was determined with a field kit using the modified permanganate oxidizable C method [17] [18] that is sensitive to land management changes. Sample and standard absorbance was read on a Hach (Hach Company, Boulder, CO) colorimeter at $550 \mathrm{~nm}$. In this method, the bleaching of the purple permanganate color is proportional to the amount of oxidizable $\mathrm{C}$ in the soil (i.e., the greater the color loss, the greater the amount of oxidizable C).

\subsection{Microbial Biomass and Basal Respiration}

Microbial biomasswas measured by the substrate-induced respiration method (SIR) [19] using $25 \mathrm{~g}$ soil and 5 $\mathrm{g} \cdot \mathrm{kg}^{-1}$ glucose. $\mathrm{CO}_{2}$ production was measured within $3 \mathrm{~h}$ of glucose addition using a LI-6200 infra-red gas analyzer. Separate $25 \mathrm{~g}$ soil samples were wetted to approximately $60 \%$ of total porosity and incubated at $20^{\circ} \mathrm{C}$ for 8 days before measuring basal respiration $\left(24 \mathrm{~h} \mathrm{CO}_{2}\right.$ production) with an infra-red gas analyzer.

\subsection{Fungi and Bacteria (Microscope)}

Fungal hyphal length and biomass were estimated by epifluorescent microscopy [20]. Briefly, hyphae were extracted from $10 \mathrm{~g}$ soil (dry wt. equivalent) by shaking in $95 \mathrm{ml}$ dilute Ringers solution for 10 minutes. The samples were then diluted in $0.3 \mathrm{M}$ phosphate buffer to a final dilution of $1 \mathrm{mg}$ soil ml${ }^{-1}$. Diluted samples $(1 \mathrm{ml})$ were stained with $0.5 \mathrm{ml}$ fluorescent brightener 28 (Sigma-Aldrich, St. Louis, MO) for $30 \mathrm{~min}$. at room temperature in the dark, filtered onto $0.2 \mu \mathrm{m}$ blackened Millipore filters, and viewed at $400 \times$ magnification with a 01 filter set. Hyphal lengths and widths were measured on 20 fields per sample, and converted to biomass [21].

Bacteria were stained with SYBR Green I (Invitrogen Corp., Carlsbad, CA) to estimate total number and biomass. Soil extractions followed the same method as those for determining fungal biomass. Samples $(1 \mathrm{ml})$ were filtered onto $0.02 \mu \mathrm{m}$ what mananodisc filters using $<80 \mathrm{~mm} \mathrm{Hg}$ pressure. Each filter was then stained with 15 
$\mu \mathrm{l}$ SYBR Green I $\left(10^{-3}\right.$ dilution in filter-sterilized $\left.\mathrm{H}_{2} \mathrm{O}\right)$, incubated in the dark for $15 \mathrm{~min}$, and viewed using an epifluorescent microscope with a 09 filter set. Cell numbers and diameters were measured on 10 fields per sample, averaging 20 - 50 cells per field. Total biomass was calculated from the microscope measurements

\subsection{Phospholipid Fatty Acid (PLFA)}

Freeze-dried mineral soil subsamples were utilized to assess microbial community structure. Mass spectral analysis identified numerous compounds between $\mathrm{C} 14$ to $\mathrm{C} 22$ in $\mathrm{C}$ chain length, of which 16 were used as microbial biomarkers [21]-[23]. Total microbial biomass was calculated by summing these 16 biomarkers. Subsets of the biomarkers were used to estimate gram-negative bacteria (cy17:0, cy19:0, 16:1 $\omega 9,16: 1 \omega 7,18: 1 \omega 5 \mathrm{c}$, and 18:167) and gram-positive bacteria biomarkers (i15:0, a15:0, i16:0, i17:0, a17:0, and 10me16:0) discriminate between groups. Two isomers of C18:2n6 (trans and cis) were used to estimate the fungal group [22] and 10me 16:0 were used to represent the actinobacteria [23].

PLFA extractions were performed using $5 \mathrm{~g}$ of freeze-dried soil with a single-phase mixture of chloroform, methanol, and phosphate buffer [24] then fractionated into neutral, glyco-, and phospholipids [25]. The phospholipids are then esterfied and reconstituted in hexane prior to analysis [26]. A capillary column was used for compound separation. Identification and quantification of the each specific fatty acid methylester (FAME) was established using commercially available standards (Accustandard, Sigma-Aldrich, St. Louis, Missouri, USA) through electron ionization on a quadrapole mass selective detector (Agilent $6890 \mathrm{~N} / 5973 \mathrm{~N}$ gas chromatograph/ mass spectrometer, Santa Clara, CA, USA). Quantification ( $\mu \mathrm{mol}$ of PLFA $/ \mathrm{kg}$ oven-dry material) of samples is based on calibration curves derived from individual FAME standards.

\subsection{Statistical Analyses}

Analysis of variance using the mixed model (SAS Inc., Cary, NC) was used to test for differences in soil properties among harvested and unharvested control stands. The least significant difference (LSD) test of significance was used to assess the differences of means among the clear cut harvested and uncut treatments at $P<0.10$. Linear regression analysis was used to explore the relationships of active $\mathrm{C}$ and individual soil chemical or microbial properties (SAS Inc., Cary, NC).

\section{Results}

In general, soil properties still reflect the impact of land management 40 years after harvest and site preparation operations. The surface organic horizons had lower $\mathrm{C}$ and $\mathrm{N}$ contents, but only $\mathrm{N}$ was significantly lower in the managed stands as compared to the unharvested stands (Table 2). Total bulk density was slightly (8\%), yet significantly higher in the managed stand (Table 2$)$. In addition, the surface $(0-5 \mathrm{~cm})$ mineral soil C, N, CEC, and base saturation were lower in the managed stand than in the control, but only CEC values were significantly different among these two stand types.

The microbial measurements showed mixed responses to legacy stand management. Although not significant, active $\mathrm{C}$ was less in the managed stand; whereas SIR, respiration at day 8, bacteria and hyphal biomass were greater 40 years after management, but not significantly (Table 3 ). Total bacteria were significantly greater in the managed stand as compared to the unharvested stands.

Our objective for this study was to determine if active $\mathrm{C}$ could be used as a low-cost, time efficient field method for determining organic matter quality in lieu of using lab- and cost-intensive measurements. For each stand type (managed and unharvested) we used a simple linear regression to evaluate the relationships. Active $\mathrm{C}$ was positively correlated with several microbial measures (Table 4). Interestingly, only SIR, basal respiration, and the microscope fungi: bacteria ratios were significantly correlated with active $\mathrm{C}$ in the unharvested and managed stands whereas total bacteria, bacterial biomass, hyphal length, hyphal biomass, actinomycetes (PFLA), and fungi (PFLA) were only significantly correlated with active $\mathrm{C}$ in the managed stands. As expected, the best relationship with active $\mathrm{C}$ was with total $\mathrm{C}$ ( $P \leq 0.0001$ for both the managed and unharvested stands; Figures 1(a)-(b)).

\section{Discussion}

Using the unharvested stand as a reference assumes that both stand types were identical when the managed 
Table 2. Mean surface organic horizon and mineral soil ( $0-5 \mathrm{~cm}$ depth) characteristics in managed and unharvested stands in northern Idaho. Values in parentheses are the standard error of the mean.

\begin{tabular}{cccc}
\hline Soil property & Stand type & \\
& Managed & Unharvested & $P$ \\
\hline Surface organic horizons & & & 0.3855 \\
Carbon $(\mathrm{Mg} / \mathrm{ha})$ & $48.6(4.9)$ & $59.4(3.2)$ & 0.0152 \\
Nitrogen $(\mathrm{kg} / \mathrm{ha})$ & $1095(130)$ & $1597(170)$ & 0.4258 \\
Mineral soil $(0-5 \mathrm{~cm})$ & & & 0.4153 \\
Carbon $(\mathrm{Mg} / \mathrm{ha})$ & $18.0(2.1)$ & $21.4(2.4)$ & 0.5253 \\
Nitrogen $(\mathrm{kg} / \mathrm{ha})$ & $2838(215)$ & $2913(232)$ & 0.0152 \\
$\mathrm{pH}$ & $6.2(0.1)$ & $6.3(0.1)$ & 0.0401 \\
Bulk density $\left(\mathrm{Mg} / \mathrm{m}^{3}\right)$ & $0.72(0.08)$ & $0.67(0.05)$ & 0.2081 \\
\hline Cation exchange capacity $(\mathrm{cmols} / \mathrm{kg})$ & $24.4(3.5)$ & $28.5(3.9)$ & $71.4(5.3)$ \\
\hline
\end{tabular}

Table 3. Mean soil microbial measurements in the mineral soil $(0-5 \mathrm{~cm}$ depth $)$ in managed and unharvested stands in northern Idaho.Values in parentheses are the standard error of the mean.

\begin{tabular}{cccc}
\hline Soil property & Stand type & & \\
\hline & Managed & Unharvested & \\
\hline & & & \\
Active $\mathrm{C}(\mathrm{mg} / \mathrm{kg})$ & $842.0(251.5)$ & $934.8(221.7)$ & 0.2930 \\
SIR $(\mathrm{mg} / \mathrm{kg})$ & $500.5(235.1)$ & $416.5(125.2)$ & 0.2858 \\
Basal respiration $(\mu \mathrm{g} / \mathrm{h} / \mathrm{g}$ soil) & $0.061(0.030)$ & $0.049(0.011)$ & 0.2400 \\
Total bacteria $\left(\times 10^{9}\right.$ cells/g soil) & $4.23(0.21)$ & $2.69(0.14)$ & 0.0443 \\
Bacterial biomass $(\mu \mathrm{g} / \mathrm{g}$ soil) & $458.4(176.2)$ & $374.8(178.4)$ & 0.2081 \\
Hyphal biomass $(\mu \mathrm{g} / \mathrm{g}$ soil) & $2914.7(974.3)$ & $2657.6(1321.2)$ & 0.5159 \\
Hyphal length $(\mathrm{m} / \mathrm{g}$ soil $)$ & $925.4(292.5)$ & $950.5(473.6)$ & 0.8544 \\
Fungi: bacteria $(\mathrm{microscope})$ & $9.5(3.0)$ & $7.9(1.0)$ & 0.2672 \\
Gram positive $(\mu \mathrm{mol}$ of PFLA $/ \mathrm{kg})$ & $50.89(17.84)$ & $34.57(10.52)$ & 0.0100 \\
Gram negative $(\mu \mathrm{mol}$ of PFLA $/ \mathrm{kg})$ & $33.17(9.76)$ & $25.56(6.89)$ & 0.0221 \\
Actinomycetes $(\mu \mathrm{mol}$ of PFLA $/ \mathrm{kg})$ & $1.62(0.44)$ & $1.35(0.34)$ & 0.0911 \\
Fungi $(\mu \mathrm{mol}$ of PFLA/kg) & $10.82(3.48)$ & $8.95(2.98)$ & 0.1315 \\
\hline
\end{tabular}

stands were harvested and had not been selectively affected by biological factors since that time [27] [28]. In this area of northern Idaho, past timber sale records indicate that this assumption is likely correct (Idaho Panhandle National Forest Timber Stand Management Database). We also assumed that since this was a relatively narrow geographic area, that climate had not changed among our stand types. Clearcut harvesting alters hydrological processes [29] [30], surface organic matter, and carbon [7]. Using the unharvested stand as a baseline reference for changes in the managed stand, the impacts of clearcut harvesting $40 \mathrm{yrs}$ ago on soil properties were still evident, though the effects were not consistent among properties nor were they particularly sizable when detected (Table 2). Forest floor $\mathrm{N}$ content showed the greatest difference due to harvesting ( $31 \%$ lower in managed compared to unharvested stands). We attribute this to the slow development of the Oe and Oa horizons during stand regeneration in this forest type or that the incremental tree growth in the managed stand exceeds that of the unharvested stand thereby moving more $\mathrm{N}$ into the aboveground portion of the stand [29]. Cation ex- 
Table 4. Linear regression relationship of microbial measurements to active $\mathrm{C}$ in the mineral soil $(0-5 \mathrm{~cm}$ depth) in managed and unharvested stands in northern Idaho. Values in bold indicate a significant relationship between the variable and active $\mathrm{C}$ at $P<0.20$.

\begin{tabular}{|c|c|c|c|c|}
\hline \multirow[t]{2}{*}{ Soil property } & \multicolumn{2}{|c|}{ Managed stand } & \multicolumn{2}{|c|}{ Unharvested stand } \\
\hline & $\mathrm{F}$ & $P$ & $\mathrm{~F}$ & $P$ \\
\hline $\mathrm{SIR}(\mathrm{mg} / \mathrm{kg})$ & 3.629316 & 0.067473 & 4.186894 & 0.063296 \\
\hline Basal respiration $(\mu \mathrm{g} / \mathrm{h} / \mathrm{g}$ soil $)$ & 2.508301 & 0.137263 & 4.329197 & 0.059552 \\
\hline Total bacteria $\left(\times 10^{9}\right.$ cells/g soil $)$ & 2.896061 & 0.112574 & 0.787941 & 0.392168 \\
\hline Bacterial biomass ( $\mu \mathrm{g} / \mathrm{g}$ soil) & 2.021855 & 0.178601 & 0.001147 & 0.973536 \\
\hline Hyphal biomass ( $\mu \mathrm{g} / \mathrm{g}$ soil) & 0.00911 & 0.925416 & 0.037679 & 0.849395 \\
\hline Hyphal length (m/g soil) & 3.02617 & 0.105536 & 0.084167 & 0.77668 \\
\hline Fungi: bacteria (microscope) & 4.40091 & 0.056021 & 1.510192 & 0.05601 \\
\hline Gram positive (PFLA) & 1.19006 & 0.295124 & 0.495088 & 0.494077 \\
\hline Gram negative (PFLA) & 1.420241 & 0.254666 & 0.775937 & 0.394381 \\
\hline Actinomycetes (PFLA) & 2.887063 & 0.113082 & 1.781503 & 0.204871 \\
\hline Fungi (PFLA) & 2.276916 & 0.155228 & 0.887178 & 0.363418 \\
\hline
\end{tabular}

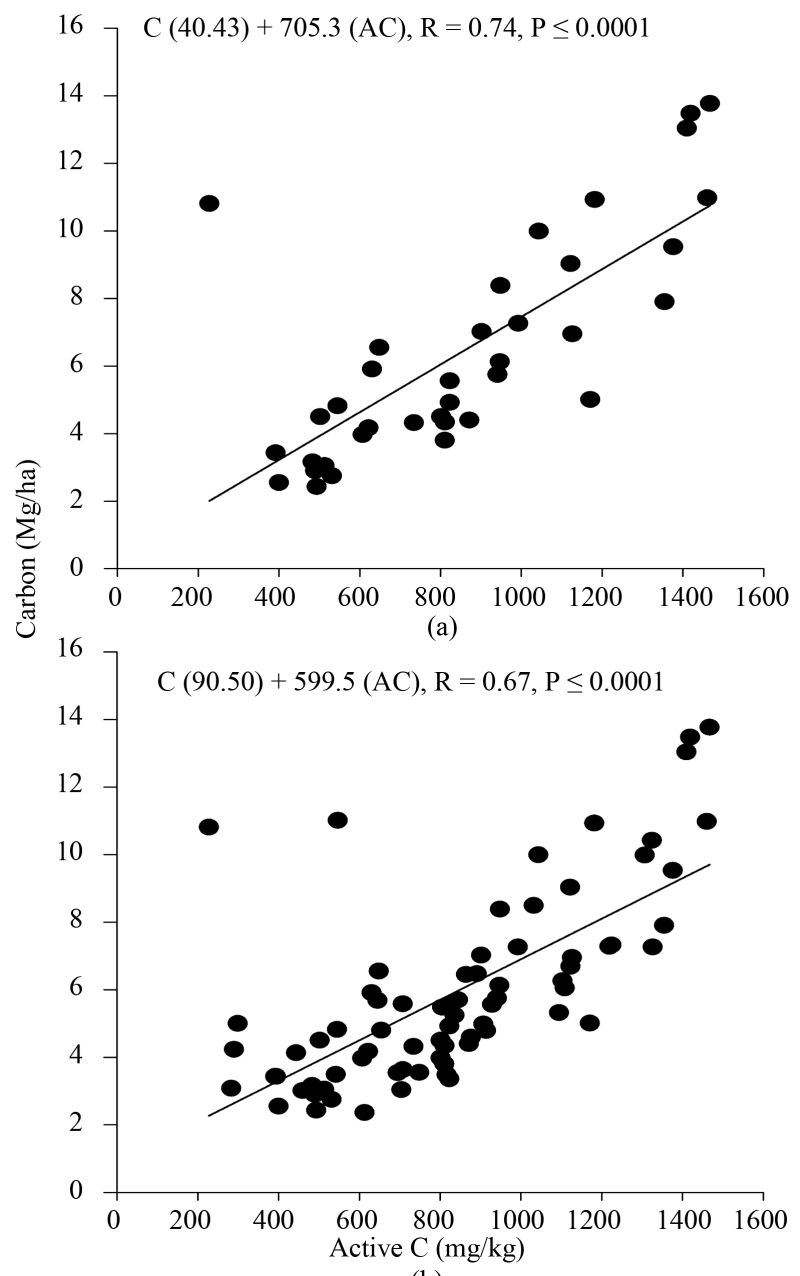

(b)

Figure 1. Correlation of $\mathrm{C}(\mathrm{Mg} / \mathrm{ha})$ to active $\mathrm{C}(\mathrm{mg} / \mathrm{kg})$ in (a) managed and (b) unharvested forest soil $(0-5 \mathrm{~cm})$ in northern Idaho. 
change capacity was $14 \%$ lower in managed compared to unharvested stands yet was still well above the threshold level for ash-cap soil. In addition, bulk density remained significantly higher in the managed stand than unmanaged stand as a consequence of clearcut harvest operations, piling slash for burn piles, the susceptibility of volcanic ash-cap soil to compaction, and the lack of a freeze/thaw cycle in this area [31]. However, we anticipate the small increase in bulk density with harvesting ( $8 \%$ higher compared to unharvested stands) will have a nominal effect on soil and plant processes [32].

Microorganisms are an essential constituent of soil quality and productivity, particularly after harvest operations [4] [33] [34]. Microbes are responsible for mediating wood decomposition, nitrogen conversion, and mycorrhizal activity, thereby affecting plant growth [35] and they depend on organic matter for energy to facilitate the transformation of nutrients making them available for plant uptake [36]. Harvesting can alter microbial activity by changing the amount and type of organic matter, altering soil temperature and moisture, and increasing soil bulk density [37]. After 40 years, microbial measures on our harvested sites had recovered to, or exceeded, levels in the unharvested stand. Stand recovery after harvesting in the Oregon Cascades indicated that increasing time after harvesting resulted in soil properties (soil organic matter and C), but not litter depth or soil respiration, shifting towards unharvested conditions after 40 years [38]. We assume this observation reflects both the tolerance of microbial communities to infrequent disturbance [20] and the positive effect of the aggrading forest floor on soil temperature, moisture, nutrient and carbon inputs and, consequently, microbial community resilience. Interestingly, bacterial numbers and PLFA content (gram positive and gram negative bacterial signatures) were significantly higher in managed compared to unharvested stands. Reasons for this observation and whether ecological significance can be attached to them are unclear.

One of our objectives was to test the effectiveness of active $\mathrm{C}$ as a rapid method for determining management impacts on forest soils. Field testing of active $\mathrm{C}$ is a simple and inexpensive procedure and has been shown to be effective indicator of soil organic matter content and biological activity in other ecosystem types [12] [17]. Importantly, we tested active $\mathrm{C}$ across a wide range of soil $\mathrm{C}$ contents and microbial conditions. For example, there was a 7-fold range in total soil $\mathrm{C}$ among samples $(2-14 \mathrm{Mg} / \mathrm{ha})$ and microbial biomass ranged from approximately 50 to $1200 \mathrm{mg} \mathrm{C} / \mathrm{kg}$. Active $\mathrm{C}$ followed a similar trend as total C in both stand types (Figures 1(a)-(b)). Active $\mathrm{C}$ has also been shown to have greater sensitivity to land management or environmental gradients than particulate organic $\mathrm{C}$, microbial biomass $\mathrm{C}$, and soil organic $\mathrm{C}$ [39].

\section{Conclusion}

In our 40-year-old harvested stand, moderate changes in soil bulk density, cation exchange capacity and some PFLA measurements indicate that the soil environment is still exhibiting chemical, biological and physical changes due to harvesting. Some of the changes may be associated with the shift in overstory species, but likely the residual impacts of soil compaction and reduced total $\mathrm{C}$ are influential on the changes in microbial and active $\mathrm{C}$ response. We have shown that active $\mathrm{C}$ can be used to estimate the most readily oxidizable (active) forms of soil $\mathrm{C}$ and that this measure is related to other microbial measures such as SIR, basal respiration, PFLA fungi and the total $\mathrm{C}$ pool. This method determining the labile soil $\mathrm{C}$ pool provides a low-cost tool for forest land managers who are interested in determining changes in soil quality from harvest or site preparation practices. The active $\mathrm{C}$ field-going method offers a way to gather routine measurements. For example, in forest stands that will be harvested, measurements of active $\mathrm{C}$ may indicate the need to leave more residual slash or to limit burning operations. Alternatively, in stands that already have been harvested, active $\mathrm{C}$ may be a tool to determine site preparation or restoration needs.

\section{Acknowledgements}

The authors wish to thank Tom Rice (retired, Rocky Mountain Research Station), Dr. Mark Kimsey (University of Idaho Intermountain Forest Tree Nutrition Cooperative), Frank Gariglio, Scott Bare, Dave Hoover, Hal Swenson, Rod Kyar, Arlene Tugel, Francine Lauritie, Allyson Young and Charles Kome (USDA-NRCS) for their assistance with field data collection. We also thank Anita Falen (University of Idaho) for her assistance in the field and laboratory.

\section{References}

[1] Doran, J.W. and Parkin, T.B. (1994) Defining and Assessing Soil Quality. In: Doran, J.W., Coleman, D.C., Bezdicek, 
D.F. and Stewart, B.A., Eds., Defining Soil Quality for a Sustainable Environment, Soil Science Society of America, Madison, 3-21.

[2] Page-Dumroese, D., Jurgensen, M., Elliot, W., Rice, T., Nesser, J., Collins, T. and Meurisse, R. (2000) Soil Quality Standards and Guidelines for Forest Sustainability in Northwestern North America. Forest Ecology and Management, 138, 445-462. http://dx.doi.org/10.1016/S0378-1127(00)00430-8

[3] Burger, J.A. and Kelting, D.L. (1998) Soil Quality Monitoring for Assessing Sustainable Forest Management. In: Adams, M.B., Ramakrishna, K. and Davidson, E.A., Eds., The Contributions of Soil Science to the Development of and Implementation of Criteria and Indicators of Sustainable Forest Management, Soil Science Society of America, Madison.

[4] Harvey, A.E., Larsen, M.J. and Jurgensen, M.F. (1980) Biological Implication of Increasing Harvest Intensity on the Maintenance and Productivity of Forest Soils. In: Environmental Consequences of Timber Harvesting in Rocky Mountain Coniferous Ecosystems, Intermountain Research Station, Ogden, 180-210.

[5] Powers, R.F. (1997) Are We Maintaining the Productivity of Forest Lands? Establishing Guidelines through a Network of Long-Term Studies. In: Harvey, A.E. and Neuwenschwander, L., Eds., Management and Productivity of Western-Montane Forest Soils, Intermountain Research Station, Ogden, 70-81.

[6] Grigal, D.F. (2000) Effects of Extensive Forest Management on Soil Productivity. Forest Ecology and Management, 138, 167-185.http://dx.doi.org/10.1016/S0378-1127(00)00395-9

[7] Powers, R.F., Scott, D.A., Sanchez, F.G., Voldseth, R.A., Page-Dumroese, D., Elioff, J.D. and Stone, D.M. (2005) The North American Long-Term Soil Productivity Experiment: Findings from the First Decade of Research. Forest Ecology and Management, 220, 31-50. http://dx.doi.org/10.1016/j.foreco.2005.08.003

[8] Franzluebbers, A.J., Haney, R.L., Honeycutt, C.W., Schomberg, H.H. and Hons, F.M. (2000) Flush of Carbon Dioxide Following Rewetting of Dried Soil Relates to Active Organic Pools. Soil Science Society of America Journal, 64, 613623. http://dx.doi.org/10.2136/sssaj2000.642613x

[9] Moldrup, P., Yoshikawa, S., Olesen, T., Komatsu, T. and Rolston, D.E. (2003) Gas Diffusivity in Undisturbed Volcanic Ash Soils: Test of Soil-Water-Characteristic-Based Prediction Models. Soil Science Society of America Journal, 67, 41-51.http://dx.doi.org/10.2136/sssaj2003.0041

[10] Gardner, B. (2007). Field Identification of Andic Soil Properties for Soils of North-Central Idaho. In: Page-Dumroese, D.S., Miller, R.E., Mital, J., McDaniel, P. and Miller, D., Eds., Volcanic-Ash-Derived Forest Soils of the Inland Northwest: Properties and Implications for Management and Restoration. Rocky Mountain Research Station, Ft. Collins, 23-30.

[11] Page-Dumroese, D.S., Jurgensen, M.F. and Terry, T.A. (2010) Maintaining Soil Productivity during Biomass Harvesting in Western Forests. Western Journal Applied Forestry, 25, 5-10.

[12] Islam, K.R. and Weil, R.R. (2000) Soil Quality Indicator Properties in Mid-Atlantic Soils as Influenced by Conservation Management. Journal of Soil and Water Conservation, 55, 69-78.

[13] Wander, M.M. and Bidart, M.G. (2000) Tillage Practice Influences on the Physical Protection, Bioavailability and Composition of Particulate Organic Matter. Biology and Fertility of Soils, 32, 360-367. http://dx.doi.org/10.1007/s003740000260

[14] DeLuca, T.H. and Keeney, D.R. (1993) Soluble Organics and Extractable Nitrogen in Paired Prairie and Cultivated Soil of Central Iowa. Soil Science, 155, 219-228. http://dx.doi.org/10.1097/00010694-199303000-00008

[15] Soil Survey Staff (2006) Soil Taxonomy.10th Edition, US Department of Agriculture, Natural Resources Conservation, Washington DC.

[16] Sumner, M.E. and Miller, W.P. (1996) Cation Exchange Capacity. In: Sparks, D.L., Ed., Methods of Soil Analysis, Part 3: Chemical Methods, Soil Science Society of America, Madison, 1201-1230.

[17] Weil, R.R., Kankikar, I.R., Stine, M.A., Gruver, J.B. and Samson-Liebig, S.E. (2003) Estimating Active Carbon for Soil Quality Assessment: A Simplified Method for Laboratory and Field Use. American Journal of Alternative Agriculture, 18, 3-17. http://dx.doi.org/10.1079/AJAA2003003

[18] Blair, G.J., Lefroy, R.D.B. and Lise, L. (1995) Soil Carbon Fractions Based on Their Degree of Oxidation, and the Development of a Carbon Management Index for Agricultural Systems. Australian Journal of Agricultural Research, 46, 1459-1466. http://dx.doi.org/10.1071/AR9951459

[19] Anderson, J.P.E. and Domsch, K.H. (1978) A Physiological Method for the Quantitative Measurement of Microbial Biomass in Soil. Soil Biology and Biochemistry, 11, 215-221. http://dx.doi.org/10.1016/0038-0717(78)90099-8

[20] Busse, M.D., Sanchez, F.G., Ratcliff, A.W., Butnor, J.R., Carter, E.A. and Powers, R.F. (2009) Soil Carbon Sequestration and Changes in Fungal and Bacterial Biomass Following Incorporation of Forest Residues. Soil Biology and Biochemistry, 41, 220-227. http://dx.doi.org/10.1016/j.soilbio.2008.10.012

[21] Bottomley, P.J. (1994) Light Microscopic Methods for Studying Soil Microorganisms. In: Weaver, R.W., et al., Eds., Methods of Soil Analysis, Part 2: Microbiological and Biochemical Properties, Soil Science Society of America, Mad- 
ison, 81-105.

[22] Frostegard, A. and Bååth, E. (1996) The Use of Phospholipid Fatty Acid Analysis to Estimate Bacterial and Fungal Biomass in Soil. Biology and Fertility of Soils, 22, 59-65. http://dx.doi.org/10.1007/BF00384433

[23] Zelles, L., Bai, Q.Y., Beck, T. and Beese, F. (1992) Signature Fatty Acids in Phospholipid and Lipopolysaccharides as Indicators of Microbial Biomass and Community Structure in Agricultural Soils. Soil Biology and Biochemistry, 24, 317-323. http://dx.doi.org/10.1016/0038-0717(92)90191-Y

[24] White, D.C., Meadows, P., Eglinton, G. and Coleman, M.L. (1993) In Situ Measurement of Microbial Biomass, Community Structure and Nutritional Status. Philosophical Transactions: Physical Sciences and Engineering, 344, 59-67. http://dx.doi.org/10.1098/rsta.1993.0075

[25] Frostegard, A., Tunlid, A. and Bååth, E. (1991) Microbial Biomass Measured as Total Lipid Phosphate in Soils of Different Organic Content. Journal of Microbiological Methods, 14, 151-163. http://dx.doi.org/10.1016/0167-7012(91)90018-L

[26] Frostegard, A., Bååth, E. and Tunlid, A. (1993) Shifts in the Structure of Soil Microbial Communities in Limed Forests as Revealed by Phospholipid Fatty Acid Analysis. Soil Biology and Biochemistry, 25, 723-730. http://dx.doi.org/10.1016/0038-0717(93)90113-P

[27] Dyck, W.J. and Cole, D.W. (1994) Strategies for Determining Consequences of Harvesting and Associated Practices on Long-Term Productivity. In: Dyck, W.J., Cole, D.W. and Comerford, N.B., Eds., Impacts of Forest Harvesting on Long-Term Site Producitivity, Chapman and Hall, London, 13-40. http://dx.doi.org/10.1007/978-94-011-1270-3 2

[28] Pennock, D.J. and van Kessel, C. (1997) Clear-Cut Forest Harvest Impacts on Soil Quality Indicators in the Mixedwood Forest of Saskatchewan, Canada. Geoderma, 75, 13-32. http://dx.doi.org/10.1016/S0016-7061(96)00075-4

[29] Seidel, K.W. (1980) Diameter and Height Growth of Suppressed Grand Fir Saplings after Overstory Removal. US Department of Agriculture, Forest Service Research Paper, PNW-RP-275.

[30] Neary, D.G. and Hornbeck, J.W. (1994) Impacts of Harvesting and Associated Practices on Off-Site Environmental Quality. In: Dyck, W.J., Cole, D.W and Comerford, N.B., Eds., Impacts of Forest Harvesting on Long-Term Site Productivity, Chapman and Hall, London, 81-118. http://dx.doi.org/10.1007/978-94-011-1270-3_4

[31] Page-Dumroese, D.S., Jurgensen, M.F., Tiarks, A.E., Ponder Jr., F., Sanchez, F.G., Fleming, R.L., et al. (2006) Soil Physical Property Changes at the North American Long-Term Soil Productivity Sites: 1 and 5 Years after Compaction. Canadian Journal of Forest Research, 36, 551-564. http://dx.doi.org/10.1139/x05-273

[32] Ponder Jr., F., Fleming, R.L., Berch, S., Busse, M.D., Elioff, J.D., Hazlett, P.W., et al. (2012) Effects of Organic Matter Removal, Soil Compaction and Vegetation Control on 10th Year Biomass and Foliar Nutrition: LTSP Continent-Wide Comparisons. Forest Ecology and Management, 278, 35-54. http://dx.doi.org/10.1016/j.foreco.2012.04.014

[33] Larsen, M.J., Harvey, A.E. and Jurgensen, M.F. (1980) Residue Decay Processes and Associated Environmental Functions in Northern Rocky Mountain Forests. In: Environmental Consequences of Timber Harvesting in Rocky Mountain Coniferous Ecosystems, Intermountain Research Station, Ogden, 157- 174.

[34] Mroz, G.D., Jurgensen, M.F., Harvey, A.E. and Larsen, M.J. (1980) Effects of Fire on Nitrogen and Forest Floor Horizons. Soil Science Society of America Journal, 44, 395-400. http://dx.doi.org/10.2136/sssaj1980.03615995004400020038x

[35] Jurgensen, M.F., Harvey, A.E., Graham, R.T., Page-Dumroese, D.S., Tonn, J.R., Larsen, M.J. and Jain, T.B. (1997) Impacts of Timber Harvesting on Soil Organic Matter, Nitrogen, Productivity, and Health of Inland Northwest Forest. Forest Science, 43, 234-251.

[36] Entry, J.A., Stark, N.M. and Loewenstein, H. (1986) Effect of Timber Harvesting on Microbial Biomass Fluxes in a Northern Rocky Mountain Forest Soil. Canadian Journal of Forest Research, 16, 1076-1081. http://dx.doi.org/10.1139/x86-186

[37] Bailey, V.L., Smith, J.L. and Bolton, H. (2002) Fungal-to-Bacterial Rations in Soils Investigated for Enhanced C Sequestration. Soil Biology and Biochemistry, 34, 393-395. http://dx.doi.org/10.1016/S0038-0717(02)00033-0

[38] Griffiths, R.P. and Swanson, A.K. (2001) Forest Soil Characteristics in a Chronosequence of Harvested Douglas-Fir forests. Canadian Journal of Forest Research, 31, 1871-1879. http://dx.doi.org/10.1139/cjfr-31-11-1871

[39] Culman, S.W., Snapp, S.S., Freeman, M.A., Schipanski, M.E., Beniston, J., Lal, R., Drinkwater, L.E., Franzluebbers, A.J., Glover, J.D., Grandy, A.S., Lee, J., Six, J., Maul, J.E., Mirksy, S.B., Spargo, J.T. and Wander, M.M. (2012) Permanganate Oxidizable Carbon Reflects a Processed Soil Fraction That Is Sensitive to Management. Soil Science Society of America Journal, 76, 494-504. http://dx.doi.org/sssaj2011.0286 
Scientific Research Publishing (SCIRP) is one of the largest Open Access journal publishers. It is currently publishing more than 200 open access, online, peer-reviewed journals covering a wide range of academic disciplines. SCIRP serves the worldwide academic communities and contributes to the progress and application of science with its publication.

Other selected journals from SCIRP are listed as below. Submit your manuscript to us via either submit@scirp.org or Online Submission Portal.
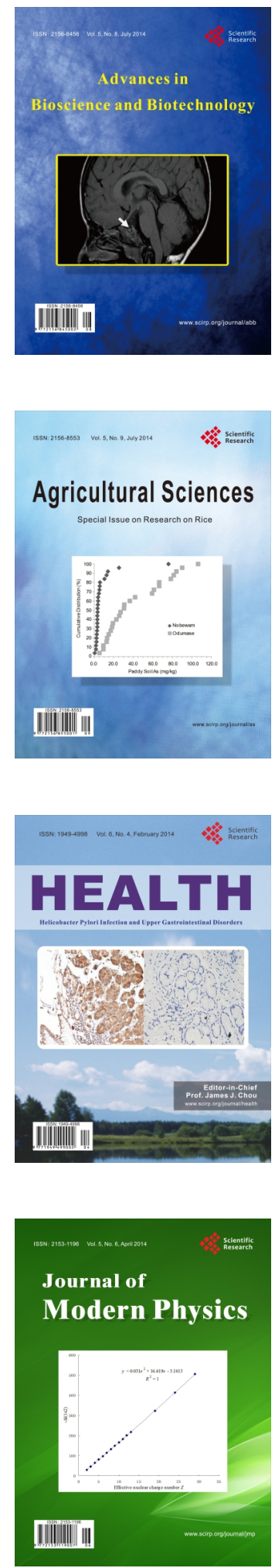
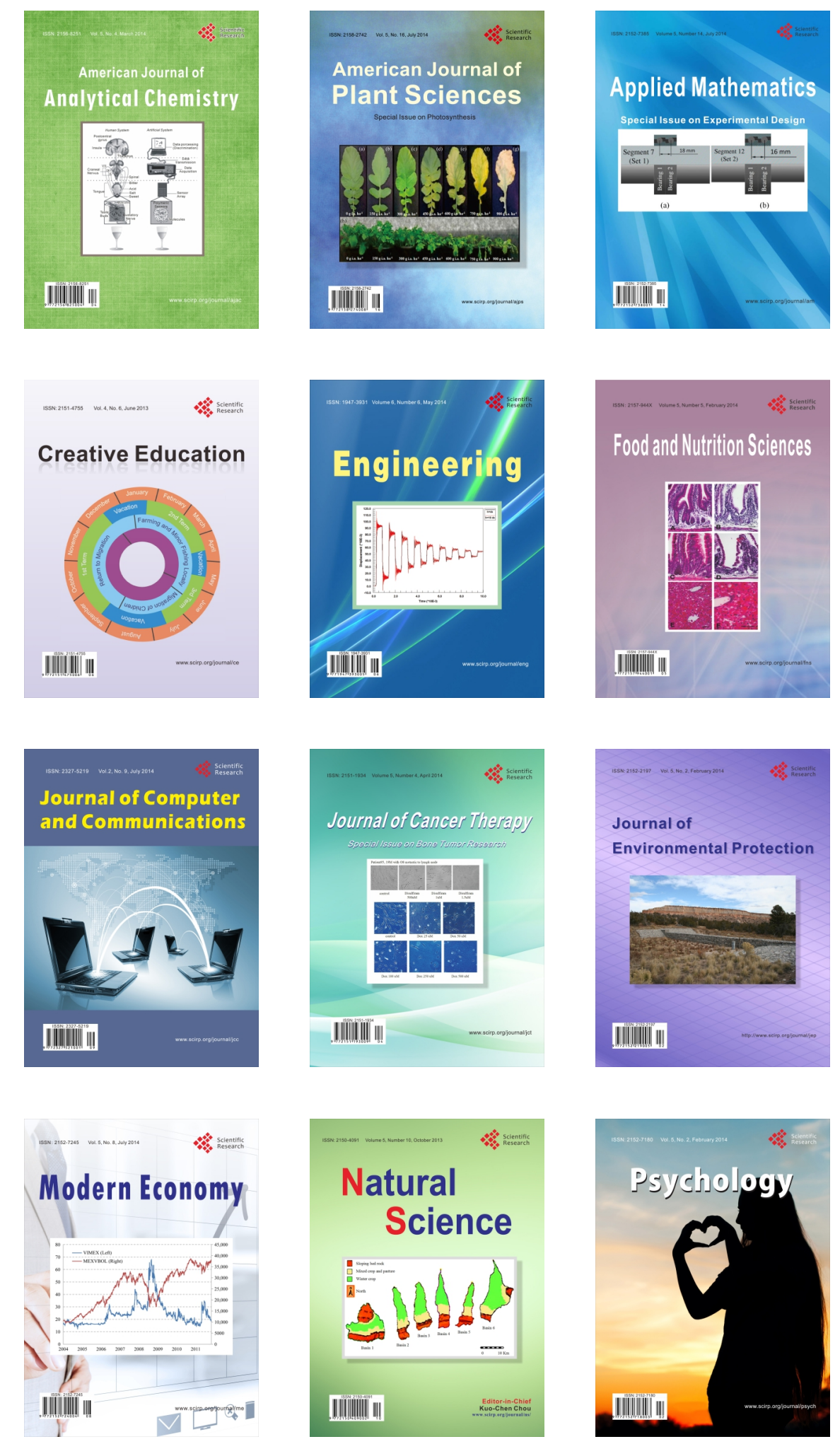